\title{
Regulatory Practices of Money Broking Business in Selected Countries
}

\author{
Rupa Dheerasinghe ${ }^{1}$
}

\begin{abstract}
Since 1980 Money Brokers (MBs) have been operating in Sri Lanka as key players in the inter bank call money market, government securities market and foreign exchange market. Money broking firms start operation after obtaining a 'no objection' letter from the Central Bank of Sri Lanka (CBSL). Currently, neither the CBSL nor any other regulatory authority regulate or supervise these institutions. Therefore, this paper intends to examine regulatory practices of money broking companies in selected countries with the view of assessing the need for and the scope of regulating money broking firms in Sri Lanka. This study is based on the information collected from 21 Central Banks/Monitory Authorities in various countries of the world, where responses were obtained through an e-mail survey conducted in late 2004. The study clearly indicates that whenever, the firms are only involved in traditional money broking activities i.e., act as an agent between lender and borrower for a commission, authorities do not regulate or supervise their activities mainly because they do not hold public funds and therefore, no systemic risk is involved. However, majority of the countries in the sample issue license or other form of approval mainly for maintaining the professional standards and monitoring the developments in this sector. In many countries, self regulatory organizations hold the responsibility of supervising and regulating money broking activities. The paper concludes that the money broking industry in Sri Lanka too needs to develop a self regulatory framework to persuade firms to maintain self discipline within the industry preferably through the existing Money Brokers Association and that the Association should endeavour to enhance its reputation by introducing quality services and practice to its members and to the market and eventually achieve the recognition of the authorities. (JEL G28)
\end{abstract}

\section{Introduction}

Money Brokers have been in operation in Sri Lanka since 1980 and they are key players in the inter bank call money market, government securities market and foreign exchange market.

1/ The author wishes to express her sincere gratitude and thanks to Dr. D.S. Wijesinghe, Assistant Governor, who provided necessary guidance throughout this study and to Mrs. Kusum Dassanayaka, Deputy Director, for providing historical information on Sri Lankan money broking industry. The author appreciates the friendship of her colleagues who attended the IMF Training Programme on Financial Programming and Policy - January/ March 2003, for assisting to collect information relating to their countries. 
Currently, ten money broking companies are operating in Sri Lanka. Except one firm², all the other companies are registered as private limited liability companies. The CBSL or any other regulatory authority do not regulate or supervise these institutions. Money broking firms start operation after obtaining a 'no objection' letter issued by the CBSL which is preceded by the application made by the prospective money broking company. Sri Lanka Money Brokers' Association (SLMBA) was set up in 1995 with the membership of all seven MBs then operating in Sri Lanka ${ }^{3}$.

This paper intends to examine regulatory practices of money broking companies in selected countries with the view of assessing the need for and scope of regulating money broking firms in Sri Lanka. The study is mainly based on the outcome of an e-mail survey conducted in late 2004 to collect information in selected economies. Section II of the paper examines recent trends in the money broking business in Sri Lanka and its importance to the Sri Lankan economy. Section III provides existing legal and regulatory framework for money brokers. Section IV analyses the survey results and examines the legal and regulatory frameworks in selected economies. Section V discusses the concerns of Sri Lanka's money broking industry and examines the justifications for regulating or not regulating money broking firms in Sri Lanka. Section VI concludes the paper with observations and recommendations.

\section{Role of the Money Broking Business in Sri Lanka}

Until the first money broking company was established in Sri Lanka in early 1980, in collaboration with India, commercial banks dealt directly with each other to conclude their foreign exchange transactions and adjust their rupee liquidity positions by borrowing and lending in the call money market. With the rapid development in the financial sector, in terms of institutions, activities, new instruments as well as the trade volumes, the importance of the presence of intermediaries such as MBs was felt for conducting the foreign exchange and money market transactions more effectively and efficiently, than it would have otherwise been carried out by the commercial banks among themselves through direct communications for each and every transaction.

Money broker ${ }^{4}$ acts as a mediator to bring suppliers of funds (lenders) and users of funds (borrowers ) together enabling them to enter into a contract for money market transactions such as short term loans, foreign exchange dealings, repurchase (Repo) and reverse repurchase (Reverse Repo) agreements etc. They arrange these transactions particularly, between corporate customers such as banks, primary dealers, discount houses and dealers

2/ Pigott \& Chapman Company which operates as a partnership.

3/ The membership has increased to 10 in 2005 .

4/ Broker is an agent who brings two parties together, enabling them to enter into a contract to which he is not a principal party. His remuneration consists of brokerage, which is usually calculated as a percentage of the sum involved in the contract but may be fixed according to a tariff. Services of the brokers are used because they have specialised knowledge of certain markets or to conceal the identity of a principal, in addition to introducing buyers to sellers. in government securities. MBs do not themselves lend or borrow money. They work for a commission for arranging contracts, often for short term loans on overnight basis.

It may be argued that direct dealing between market participants (i.e., a bank with another bank) is useful for them as they do not have to pay brokerage. However, brokers have specialized knowledge of the market they operate and therefore, are able to provide a comprehensive and efficient service to their clients at a competitive price. Since the brokers disseminate current prices across the market, prices determined in such a market would be more competitive and well representative. When the brokers are active in the market, large percentage of the total volume of transactions is passed through them and therefore, they have access to the most updated market information than the individual institutions. The presence of a broker, conceals the identity of a principal, in addition to the use of their expertise to arrange the transactions. Therefore, brokers can play an important role in the development of the market while minimizing the transaction cost. They improve the market efficiency and make the task of banks and other financial dealers much easier as there is no need for them to search for another party to carry out their deals.

The first money broking company, Bartleet, Macklai \& Roy Ltd., was established in Sri Lanka on 06 February 1980 in collaboration with India. From the inception, the CBSL which felt the need for developing the money market has always been cooperative in promoting this business in Sri Lanka. Within the next 4 years another 7 companies commenced money broking business in Sri Lanka of which 2 institutions were closed down later. Most of these early MBs are collaborations either with Singapore or India. One of those companies,

\section{Table 1 - List of Money Brokers in Sri Lanka}

\begin{tabular}{|l|c|}
\hline \multicolumn{1}{|c|}{ Name of the Company } & $\begin{array}{c}\text { Date of issuing } \\
\text { 'no objection' letters }\end{array}$ \\
\hline Bartleet Mecklai and Roy Ltd. & $18-12-1979$ \\
\hline Pigott Chapman \& Company & $11-02-1980$ \\
\hline Forbs MBs Ltd. (Since 18-07-1994 Vanik Money Brokers Ltd.) & $18-02-1980$ \\
\hline $\begin{array}{l}\text { MB Financial Services (Pvt) Ltd. } \\
\text { (Since 01-05-2000 First capital Money Brokers Ltd.) }\end{array}$ & $20-05-1980$ \\
\hline Mercantile Finance Brokers Ltd. & $05-05-1981$ \\
\hline $\begin{array}{l}\text { Ceylinco Sec. \& Financial Services } \\
\text { (Since 09-06-1996 CSF Money Broking Company) }\end{array}$ & $11-01-1983$ \\
\hline $\begin{array}{l}\text { Seylan Merchant Bank Ltd. } \\
\text { (Since 01-10-1996 SMB Money Brokers (Pvt) Ltd. }\end{array}$ & $13-10-1994$ \\
\hline Capital Alliance Money Brokers Ltd. & $05-01-2004$ \\
\hline Taprobane Investments (Pvt) Ltd. & $27-09-2004$ \\
\hline George Steuart Financial Services Ltd. & $10-08-2005$ \\
\hline
\end{tabular}

Source : Domestic Operations Department, Central Bank of Sri Lanka 
George Steuart Financial Services Ltd. which was affected by the bomb attack at the CBSL in 1996, recommenced its business in October 2005. Including this company and another three companies that entered the market recently, ten money broking companies are currently operating in Sri Lanka. However, Mercantile Finance Brokers Ltd. which had been operated since 1981 is temporally out of business since 31 January 2006 due to lack of professional skills. MBs in Sri Lanka carry out their transactions mainly through "voice broking' i.e., a transaction is concluded over the telephone. The other popular method of dealing, i.e., 'electronic broking', is not widely used in Sri Lanka as yet. All transactions concluded verbally over the telephone are confirmed immediately to counterparties through facsimile or telex.

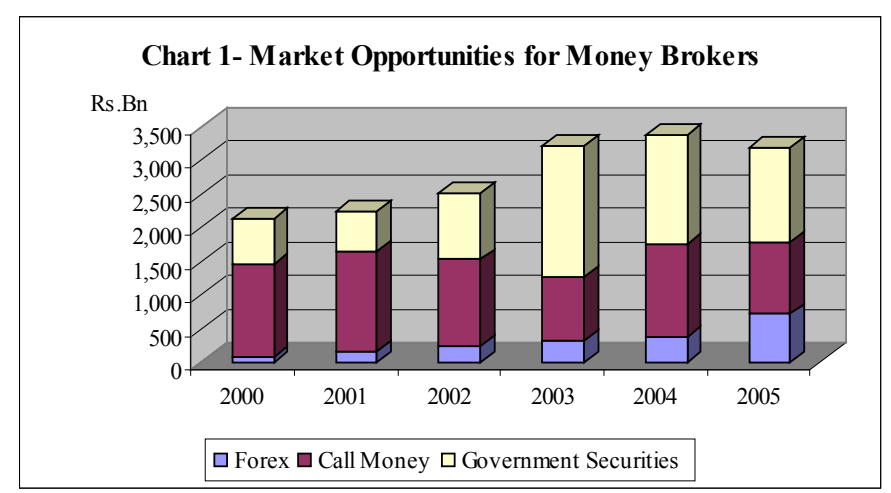

The market trade volumes have increased gradually over the past few years, except 2005 (Chart 1). Developments in the foreign exchange market, government securities market and the progressive private sector involvement in the market created more business opportunities expanding the trade volumes in the market. Similarly, trade volumes ${ }^{5}$ of MBs too increased over the last several years. However, a large share of existing government securities market, foreign exchange market and call money market is yet to be harnessed by the brokers (Table 2).

In Sri Lanka most of the money broking firms provide broking services on $(a)$ inter bank call money, $(b)$ foreign exchange and $(c)$ trading in government securities. MBs services in the inter bank call money market are to facilitate borrowing and lending transactions between the commercial banks. Currently, 23 commercial banks operating in Sri Lanka are the prospective customers of the MBs. As the trade volumes of the inter bank call money

5/ Based on trade volumes reported by all money brokers who operated in respective years.
Table 2 - Market Share of Money Brokers ${ }^{6}$

(Values are given in Rs. million)

\begin{tabular}{|l|c|c|c|c|c|c|}
\hline \multirow{2}{*}{ Activity } & \multicolumn{3}{|c|}{$\mathbf{2 0 0 4}$} & \multicolumn{3}{|c|}{$\mathbf{2 0 0 5}$} \\
\cline { 2 - 7 } & $\begin{array}{c}\text { Total } \\
\text { Market }\end{array}$ & Brokers & $\begin{array}{c}\text { Market } \\
\text { Share (\%) }\end{array}$ & $\begin{array}{c}\text { Total } \\
\text { Market }\end{array}$ & Brokers & $\begin{array}{c}\text { Market } \\
\text { Share (\%) }\end{array}$ \\
\hline Forex & 380,613 & 234,264 & 61.5 & 708,905 & 476,216 & 67.2 \\
\hline Call Money & $1,363,490$ & $1,042,186$ & 76.4 & $1,057,238$ & 873,204 & 82.6 \\
\hline $\begin{array}{l}\text { Government } \\
\text { Securities }\end{array}$ & $1,622,740$ & 385,947 & 23.8 & $1,429,831$ & 533,326 & 37.3 \\
\hline Total & $3,366,843$ & $1,662,397$ & 49.4 & $3,195,973$ & $1,882,746$ & 58.9 \\
\hline
\end{tabular}

Sources: Money Brokers, Central Bank of Sri Lanka

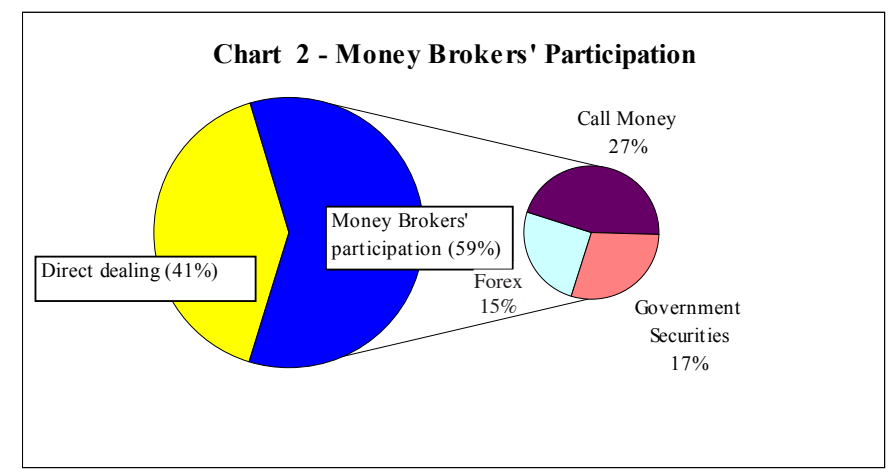

market is increasing, opportunities for money brokers in the call money market are expanding every year. More than 80 per cent of the call money market transactions are now carried out through MBs.

6/ Explanatory Notes for data used in Table 1:

o MBs trade volumes: Rupee equivalent of total volume of transactions (turnover) reported by $10 \mathrm{MBs}$ under different business categories for reference year.

Market Forex Volume : Rupee equivalent of total inter bank forex transactions excluding transactions with the CBSL.

o Market Call Money Volume : Total amount of call money transactions took place during the year.

o Government Securities : Total value of transactions where a primary dealer is one party of the transaction. To avoid the under estimation of MBs participation resulted purely due to the nature of the marke (as discussed in the text) 75 per cent of the Repo and reverse Repo transactions are excluded from the total market volume. 


\section{A. Inter-bank Foreign Exchange Marke}

In the foreign exchange market, MBs act as an intermediary for financial institutions in arranging spot or forward foreign exchange transactions, dealing with foreign currency banking units of the commercial banks, arranging swaps, cross currency transactions and deposits. The foreign exchange transactions in the country have increased over the last several years enhancing the opportunities for MBs to expand their activities. Similarly, activities in this market expanded significantly in 2005, due to large foreign currency inflows to the government and the private sector relating to tsunami relief and rehabilitation work, increased export proceeds and private remittances and the benefits of debt moratorium. As a result, the total turnover of MBs on foreign exchange transactions more than doubled during 2005. Around 67 per cent of the total foreign exchange transactions in the county are now carried out through MBs.

\section{B. Call Money Market}

MBs services in the inter bank call money market are to facilitate borrowing and lending transactions among the commercial banks. Currently, 23 commercial banks operating in Sri Lanka are the prospective customers of the MBs. The inter-bank call money market remained liquid in 2005. Market liquidity was high at the beginning of the year as the CBSL discontinued, for a short period, the absorption through auctions under open market operations and maintained the market well liquid to ensure smooth operations of the financial system following the tsunami disaster. Even though, later, CBSL conducted OMOs aggressively to absorb the excess liquidity, in general the market remained liquid throughout the year. As a result of comfortable liquidity conditions in the market during most of the year, the total call market transactions declined by 22 per cent in 2005 .

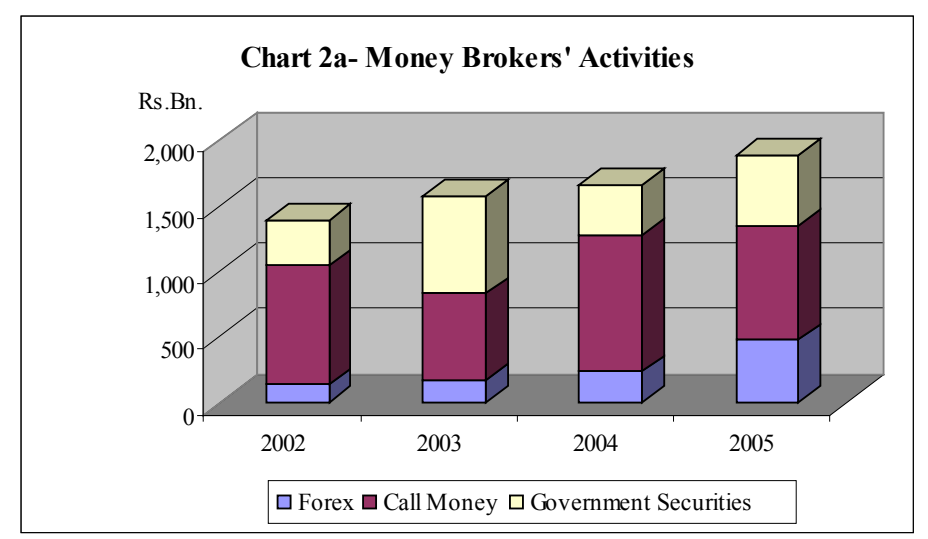

Following the slow down in overall activities, MBs participation in call money market declined by 16 per cent. However, their market share increased from 76 per cent in 2004 to 83 per cent in 2005. In addition to overnight call money transactions reported in this Table 1, MBs provide facilities to term money as well.

\section{Government Securities Market}

In the securities market, MBs are involved in making arrangements between two parties for discounting government securities in the secondary market and arranging repo/reverse repo transactions. The relatively lower involvement of MBs in government security market is partly due to the nature of the activities in the market.

More than 75 per cent of the secondary market for government securities consists of short term repurchasing (Repo) and reverse repurchasing (Reverse Repo) agreements. As most of the market players continue to hold the funds in their position for a longer period, though their overnight Repo agreements are renewed daily, the number of new arrangements for such agreements are considerably lower than the number of Repo transactions recorded as the total market volumes. Therefore, opportunities for MBs to arrange Repo/Reverse Repo agreements are lower than total market volumes. Similarly, the commission that the broker can earn by arranging a Repo/Reverse Repo transaction is insignificant compare to their transactions in other markets. This fact also makes the MBs participation in Repo/ Reverse Repo market to remain at a lower level.

In 2005, total secondary market transactions based on Treasury bills increased by 15 per cent while similar transactions on Treasury bonds declined by 24 per cent, reflecting the increased appetite for short term instruments. This trend was reflected in both repo and reverse Repo transactions as well as the outright transactions as primary dealers have continued to take a position of risk aversion, leading to an increase in short-end market transactions. As a result the overall volume of secondary market transactions declined by 12 per cent in 2005 compared to available opportunities in the previous year.

Despite the trends in overall volume of secondary market transactions, MBs participation in both outright and Repo/Revers Repo markets increased by 38 per cent in 2005 over the that of 2004. MBs market share too increased from 24 per cent in 2004 to 37 per cent in 2005 though their participation in the government securities market is still low.

In addition to these key areas, MBs active in Sri Lanka, effectively participate in term money transactions and also act as an intermediary for meeting short term funding requirements of the non- bank financial institutions such as finance companies, merchan banks, and specialized banks. They also provide brokerage services on financial derivatives, corporate bonds etc. Some companies provide services such as financial market research, advisory services and training facilities in addition to its core activity of money broking 
activities. Opportunities for MBs to expand their services to savings banks, insurance companies, provident funds and other financial institutions and offer facilities on a wide range of instruments are expanding with the evolution of the money and capital markets.

\section{Money Brokers' Income}

Table 3 - Money Brokers Income (Rs. million)

\begin{tabular}{|l|r|r|}
\hline Activity & $\mathbf{2 0 0 4}$ & $\mathbf{2 0 0 5}$ \\
\hline Forex & 39.6 & 68.8 \\
\hline Call Money & 4.5 & 8.4 \\
\hline Government Securities & 38.9 & 40.9 \\
\hline Total & 82.9 & 118.1 \\
\hline
\end{tabular}

Income received by MBs only through participation in foreign exchange, call money and government securities market increased by 42 per cent in 2005. More than 58 per cent of their income was from the brokering services in foreign exchange market and the next highest source of income was for services provided in the government securities market. Even though, trade volumes handled in the call market was relatively large, the income was small as these transactions are for very short period, i.e., overnight.

\section{Existing Legal and Regulatory Framework for Money Broking Business in Sri Lanka}

There is no legal framework for regulating money broking business in Sri Lanka ${ }^{7}$. Furthermore there is no accepted Code of Ethics and Professional Conduct ${ }^{8}$ at present to prevent malpractices or guidelines or operational instructions to regulate and supervise the activities of money broking business. Even though, there is no statutory provision in the Monetary Law Act for the CBSL to grant or refuse permission for institutions to function as MBs, the past practice and the normal procedure was to issue 'no objection' letters to firms to engage in money and foreign exchange businesses. Accordingly, then Banking Department and later Domestic Operations Department of the CBSL have issued 'no objection' letters

7/ The Securities and Exchange Commission of Sri Lanka (SEC) which was established by the Securities Council Act, No.36 of 1987 for the purpose of regulating the securities market in Sri Lanka has expanded its scope of activities by the subsequent amendments to the Act to register market intermediaries. The SEC now issues licenses to the Stock Exchange, stock brokers/dealers, unit trust management companies and registers underwriters, margin providers, credit rating agencies, investment managers and securities clearing houses but does not include money broking activities.

8/ Code of Conduct and Constitution is being drafted by the SLMBA and is in the process of being finalized. to successful applicants after reviewing money and foreign exchange market conditions prevailing at that time and track records of the institutions and their principal officers.

In the past, the CBSL has issued 'no objection' letters to 10 firms currently in business to engage in money broking business in Sri Lanka (Table 1).

It seems that money broking companies were not established during January 1983 to October 1995. This was due to some applications been turned down during this period by the CBSL as it was considered that excessive competition would lead to unhealthy practices and threaten the operations of some MBs on a profitable basis.

Historical records show that several requests by private companies, had been rejected by the CBSL in 1986 and thereafter. It was considered that a further increase in the number of money broking firms would lead to unhealthy competition among them as the banking businesses in the economy and business activities of the existing MBs had declined during the period under review.

The CBSL has rejected the issuance of 'no objection' letters due to other reasons too. A request by an another company had been rejected in July 1995 as the Memorandum and Articles of Association of the company did not contain specific provisions for carrying out money broking activities.

Since MBs are not regulated by any authority and have no official recognition, some MBs, (particularly, SLMBA), are of the view that, money broking business in Sri Lank should be brought under the preview of a regulating authority, probably, the CBSL. Though, there is no procedure or criteria laid down with regards to granting permission or issuing 'no objection' letter to operate money broking activities in Sri Lanka, common criteria has been practiced in the past. The procedure followed by the CBSL can be summarized as follows.

- Receive a request from a company who wishes to engage in money broking business.

- The Domestic Operations Department (then Banking Department) process the application. For this purpose they obtain the following documents from the proposed company.

- A copy of Memorandum and Articles of Association of the proposed company.

- A copy of the feasibility report.

- A copy of the Code of Conduct of the entity.

- Details relating to the qualifications and experience of their officers who will be in-charge of proposed money broking activities. 
- Obtain the observations of Director/Legal Department with respect to the legality of the company.

- Evaluate feasibility study, Code of Conduct and the suitability of key officers in the company.

- Evaluate the current market conditions and the future prospects of the money broking business.

- Make recommendation to the Deputy Governor for his approval.

- With the concurrence of the Deputy Governor, documents are forwarded to the Governor for his approval to issue a 'no objection letter'.

- After obtaining the Governor's approval, the Director of the Domestic Operations Department issues the 'no objection' letter to the proposed company.

- The company is expected to inform commencement of its activities to the CBSL.

- The Director of the Domestic Operations Department is the contact person for any matter relating to money brokers in the Central Bank of Sri Lanka.

Out of 11 MBs which received 'no objection' letters, Keels T \& R Ltd. (09 May 1980) was closed down due to non viability of the firm. The George Steuart Financial Services (Pvt.) Ltd. was destroyed at the bomb explosion at the CBSL in $1996^{9}$. This company has re-commenced its business on 18 August 2005. In today's context the all MBs operating in the market are firmly established and operate profitably. Some of them engage in other financial businesses in addition to money broking.

\section{Legal and Regulatory Practices in Selected Countries}

\section{A. Methodology and Limitations}

Over the last several years, the CBSL has been requested by the SLMBA to give some nature of recognition to MBs through regulating and/or supervising their business in Sri Lanka. To give due justice to their request and to make the CBSL stand clear and strong, it was

9/ George Steuart \& Company Ltd. which had been in the money broking business since 1980, has been issued with a 'no objection' letter on 10 June 1994 to cease its money broking activities and commence the same with its fully owned subsidiary George Steuart Financial Services (Pvt.) Ltd. However, the company did not stat operations as it was affected by the CBSL bomb blast in 1996 . Following the request by the parent company, the CBSL has given it's consent to re-commence the activities of the George Steuart Financial Services (Pvt.) Ltd. on 10 August 2005 decided to carry out a survey to examine regulatory practices of money broking business in other countries. This exercise was carried out through an e-mail survey conducted in late 2004. Originally, a questionnaire was sent to the SAARCFINANCE coordinators and Central Banks/Monitory Authorities of East Asian Countries. Only Central Bank of Pakistan responded to the questionnaire. Due to lack of response, it was decided to obtain information from any possible destination, regardless of geographical locations, using personal contacts. Therefore, the study is based on the information collected from Central Banks/Monitory Authorities in various parts of the world, where responses were obtained through personal contacts. Some information were collected through internet, wherever, respondents did not answer the questionnaire but provided with the addresses of relevant websites. The questionnaire is given in Annex 1 .

However, the comparison of examining regulations and supervisory framework of the MBs in various countries was found difficult due to the following constraints.

- Even if there is a common and widely used definition for MBs, in some countries, MBs are identified with additional features while others use different names to recognize the same business making it difficult to compare with the MBs discussed in this study and to identify the reasons for regulating/supervising such industry.

- In some countries, it was difficult to distinguish MBs from capital market brokers such as stock brokers, mortgage brokers etc., as the same company deals in one or more such activities.

- In some countries MBs are defined as brokers/dealers. In such instances, albeit those brokers carry out the same functions as the MBs in other countries, it is not possible to distinguish them for comparative purposes. As some brokers are involved in dealers' activities too, such countries use same set of regulations for brokers and dealers. Even though, some companies function purely as brokers, they are covered by the regulations applied to dealers as well (i.e., USA). In such countries it was difficult to distinguish whether the regulations are applied due to the involvement of broking activities or dealer activities.

- In some countries, definitions for MBs are rather complicated and subject to regulations and supervision of more than one regulator. For example in Japan MBs are identified as 'tanshi' companies ${ }^{10}$. They are divided into two types, money market broker-cum-dealers and foreign exchange brokers. Money market broker-cum-dealers provide intermediary services in money markets. They perform both dealer and broker factions and also are able to use the borrowing facilities of the Bank of Japan. However, other type of tanshi companies called foreign exchange brokers provide only brokerage services for inter-bank transactions in

10/ Please refer Table 6 for details. 


\section{Table 4 - Summary}

\begin{tabular}{|c|c|c|c|c|c|c|}
\hline \multirow[t]{2}{*}{ Category } & \multirow{2}{*}{$\begin{array}{l}\text { No. of } \\
\text { Coun- } \\
\text { tries } \\
\text { in the } \\
\text { sample }\end{array}$} & \multirow[t]{2}{*}{$\begin{array}{l}\text { License } \\
\text { Required }\end{array}$} & \multicolumn{2}{|c|}{$\begin{array}{l}\text { Regulate/ } \\
\text { supervise }\end{array}$} & \multirow{2}{*}{$\begin{array}{l}\text { Do not } \\
\text { need } \\
\text { licenses }\end{array}$} & \multirow{2}{*}{$\begin{array}{l}\text { Do not } \\
\text { regulate or } \\
\text { take lenient } \\
\text { approach } \\
\text { on } \\
\text { regulations }\end{array}$} \\
\hline & & & $\begin{array}{c}\text { By } \\
\text { govern- } \\
\text { ment }\end{array}$ & $\begin{array}{l}\text { By } \\
\text { SRO }\end{array}$ & & \\
\hline $\begin{array}{l}\text { Countries which do not } \\
\text { have MBs explicitly, but } \\
\text { broking take place in small } \\
\text { magnitude. }\end{array}$ & 5 & 0 & 0 & 0 & 5 & 5 \\
\hline $\begin{array}{l}\text { Developing or Newly } \\
\text { Developed Countries } \\
\text { where, MBs carry out } \\
\text { explicitly similar functions } \\
\text { as in Sri Lanka }\end{array}$ & 9 & 5 & 2 & 0 & 4 & 7 \\
\hline $\begin{array}{l}\text { Developing or Newly } \\
\text { Developed Countries } \\
\text { where, MBs carry out } \\
\text { additional businesses or } \\
\text { legal framework covers } \\
\text { additional activities }\end{array}$ & 3 & 3 & 3 & 0 & 0 & 0 \\
\hline $\begin{array}{l}\text { Developed countries } \\
\text { where, MBs carry out } \\
\text { additional businesses or } \\
\text { legal framework covers } \\
\text { additional activities }\end{array}$ & 4 & 4 & 3 & 1 & 0 & 0 \\
\hline Total & 21 & 12 & 8 & 1 & 9 & 12 \\
\hline
\end{tabular}

the foreign exchange market. Accordingly in Japan some tanshi companies are subject to the regulations of both the Bank of Japan and the Financial Services Agency.

- In many countries money broker activities are not distinguished from other financial services (i.e., Uganda, Moldova). In those countries money broking activities are undertaken in small scale by other financial institutions. If a commercial bank or other financial institution is carrying out broking services as a part of their business, such institutions are subject to regulations and the supervision of government authorities because of their other activities which involves commitments to depositors etc.

\section{B. Survey Results}

Out of 22 countries to whom the questionnaire was sent, 21 countries responded by sending either required information or addresses of relevant websites. Summary of the regulatory practices of MBs in different countries is given in Table 4 while detailed analysis is given in Table 6.

- Five countries in the sample, Nigeria, Uganda, Sierra Leone, Nepal and Moldova indicated that in those countries, MBs cannot be identified explicitly as the broking business is not yet developed to a significant level. Therefore, licensing or regulatory framework is not yet available. However, the respondents are not in a position to comment whether licensing or regulatory framework would be implemented eventually.

Nine developing/newly developed countries who have significant contribution from some form of money broking businesses, use similar definitions and carry out almost similar functions carried out by the MBs in Sri Lanka.

- Money Brokers in India, Pakistan, Thailand and Slovak Republic do not require licenses to operate their business. In those countries no legislation is available for supervising or regulating money broking business. However, recently, Pakistan and Thailand have shown interest in some form of supervision/regulation with the expansion in this sector. Pakistan is in the process of introducing legislative framework to issue license, regulate and supervise MBs. However, in Pakistan, a self regulatory organization (SRO) is expected to undertake the supervisory and regulation functions while Securities and Exchange Commission of Pakistan will issue licenses. The Bank of Thailand believes that MBs might have a significant role to play with the new innovations in the financial sector. Therefore, a study is being carried out to decide the functions of MBs and to see whether any form of regulation or supervision is needed.

- In Singapore and Hong Kong licenses are issued by the Monetary Authority/Central Bank while in the Philippines this function is carried out by Securities and Exchange Commission after reviewing the credentials of the company, promoters/brokers and other professionals and the viability of the company. However, these three countries, take very lenient approach in supervision and regulation of MBs but hold the authority to impose any restrictions at the time of issuing licenses.

The underlining argument for this lenient approach on supervision/regulation is that MBs are only agents working for commissions by arranging transactions as a mediator and do not deal with customers' funds and therefore, enforcing the tight regulations by government authorities is not required. 
- In the case of Taiwan, regulations are used mainly to monitor the level of activities of the MBs. However, MBs are requested to hold reserves to meet any losses to customers, caused due to incorrect decisions made by the brokers in their day to day business activities.

- The Bahrain Monitory Agency (BMA), the Central Bank of Bahrain is responsible for licensing, supervising and regulating of all banks and financial institutions. The BMALaw requires anyone wishing to operate as 'a Banking firm' to hold a license. However, the existing law does not define the banking services. Instead, the BMA currently issues licenses to money brokers and covers them under the regulatory framework. However, this situation will be changed with the implementation of the already finalized amendments to the law. Under the new legislation money broking business which is categorized under the providers of ancillary services to financial sector is identified as a non regulating business. However, these institutions are permitted to carry out distinct self contained activities and not permitted to carry out any other activity identified as 'regulated' activity i.e., conventional and Islamic banking business, insurance or investment business.

- Regulatory framework for MBs are well established in Malaysia, Malawi and Brazil. MBs are required to obtain licenses from the Ministry of Finance/Central Bank and come under the regulatory and supervisory framework of respective Central Banks.

- In Malaysia and Malawi same regulations cover money brokers as well as stock brokers/dealers while in these countries some money broking firms carry out other financial activities in addition to broking business. Therefore, licensing and regulating framework are to ensure that the activities of the MBs would not be contrary to any other provisions of the legislation which cover banking and financial institution and their actions would not be detrimental to the soundness of the financial system.

- In Brazil, activities of foreign exchange brokers are more similar to Sri Lanka and they are subject to licensing of the Brazilian Central Bank (BCB). Some MBs carry out normal broking functions but most of them are involved in various other activities which may cause systemic risk. However, they cannot engage in stock broking or dealing business. Owing to the complexity in the nature of business, MBs in Brazil are supervised and regulated by the BCB and the Securities Commission of Brazil.

- The 4 developed countries in the sample have well established regulatory framework for issuing license, regulation and supervising of MBs. In these countries and a State of USA, i.e., USA, Japan, Australia, the UK and North Dakota (a State of USA), MBs are identified together with various other activities. These countries do not distinguish money broking activities separately. In many cases the legal framework is for both dealers and brokers where one cannot decide whether the regulations are applied due to dealer or broker activities.

- In the case of the USA, general purpose brokers/dealers are required to register with the Security Exchange Commission. They are all required to register with an approved SRO simultaneously. Though, the Security Exchange Commission issues the license to function as a money broker/dealer, supervisory and regulatory functions are carried out by the SRO. However, all MBs/dealers are subject to the regulations of the particular state. Firms dealing in government securities are required to adhere to the regulations imposed by the Ministry of Finance as well. Even to become a primary dealer, the firm should be either a commercial bank or a money broker/dealer licensed by the Security Exchange Commission. Accordingly, broker/dealers are considered as the most regulated entities in the USA. However, regulations imposed by the States vary across the USA. For example, in the case of North Dakota, Department of Financial Services is responsible for licensing, regulation and supervision of MBs in that State. However, Alaska does not impose any state regulations on brokers/dealers. This is mainly due to the fact that in the USA, legislation which cover both dealer and broker activities include a wide range of activities such as stock market dealers/brokers, mortgage brokers/dealers, MBs/dealers, government bond market brokers/dealers etc. In the Federal Fund market, most of the transactions are arranged by the money brokers. The total volume of transactions per day only in the federal fund market has ranged between US dollars 60-80 billion.

- In Japan, brokers known as 'tanshi companies' cover both dealer-cum-brokers and foreign exchange brokers. The Ministry of Finance has authority to license the brokers and the Financial Services Authority (FSA) has the mandate to supervise and regulate them. However, broker-cum-dealers are supervised by the Bank of Japan (BOJ) as these companies are privileged to borrow from BOJ. However, the $\mathrm{BOJ}$ has no administrative power to regulate them and acts based on the agreement signed with the company at the beginning of the business.

- In the UK, all financial institutions are supervised and regulated by the FSA. Agency brokers/dealers who act as agents between lenders and borrowers play a similar role as MBs in other countries.

- Australia uses similar definition for MBs as in Sri Lanka and has well documented rules and regulations to supervise and regulate MBs. Some of those broking firms are involved in other financial activities in addition to broker's activities. Therefore, all financial brokers must hold a current business certificate and a license obtained from Finance Broker Supervisory Board (FBSB), a legal entity established under the Finance Brokers Control Act of 1975 (amended 2003). Their activities are regularly supervised by the FBSB. 
Table 5 - Credentials Considered for Issuing License to Money Brokers

\begin{tabular}{|c|c|c|}
\hline \multicolumn{2}{|r|}{ Credentials needed for obtaining License } & Countries \\
\hline & $\begin{array}{l}\text { Registered as a limited liability company } \\
\text { under relevant Law }\end{array}$ & $\begin{array}{l}\text { Slovak Republic Singapore, Hong Kong, Philippines Malaysia, Taiwan, } \\
\text { Malawi, Brazil, Bahrain, (Requires letter of comfort from share holders), } \\
\text { USA (some states allow proprietorships and partnerships), Australia (allows } \\
\text { proprietorships and partnerships), Japan and UK. }\end{array}$ \\
\hline 2. & Minimum capital requirement to be met & 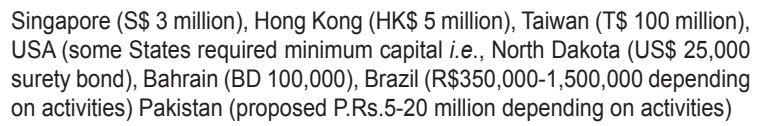 \\
\hline & $\begin{array}{l}\text { Required to comply with Company } \\
\text { constitution/Code of Conduct or specific } \\
\text { Code of Conduct approved by the licensing } \\
\text { Authority }\end{array}$ & $\begin{array}{l}\text { Singapore, Hong Kong, Philippines Malaysia, Taiwan, Malawi, Brazil, Bahrain, } \\
\text { USA (some States), Australia, Japan and UK }\end{array}$ \\
\hline & $\begin{array}{l}\text { The credentials of all share holders and key } \\
\text { officials }\end{array}$ & \multirow[b]{2}{*}{$\begin{array}{l}\text { Singapore (Need to get approval of MAS to appoint / change chief broker } \\
\text { and provide training to staff), Hong Kong (needs to prove the suitability of } \\
\text { CEO and other key officers and give written notice before changing key } \\
\text { officials), Philippines (credential of CEO and staff), Malaysia ( (rrofessional } \\
\text { qualifications), Taiwan (working experience), Pakistan (proposed to have } \\
\text { minimum educational qualifications), USA, Japan and Australia. }\end{array}$} \\
\hline 5. & $\begin{array}{l}\text { Qualifications of the Staff } \\
\text { ○ Minimum / satisfactory professional } \\
\text { qualification for CEO and key officials } \\
\text { o Properly designated / trained supporting } \\
\text { staff for dealing and settlement } \\
\text { o Working experience of brokers and staff } \\
\text { o Conditions on providing required } \\
\text { training facilities to brokers. }\end{array}$ & \\
\hline & $\begin{array}{l}\text { Providing financial statements (for existing } \\
\text { companies) or business plan/feasibility } \\
\text { study any other information required to } \\
\text { decide the suitability }\end{array}$ & $\begin{array}{l}\text { Singapore, Hong Kong, Philippines, Malaysia, Taiwan, Malawi, Brazil, } \\
\text { Bahrain, USA (some States only), Australia, Japan and UK. }\end{array}$ \\
\hline & $\begin{array}{l}\text { Brokers to register with the relevant } \\
\text { government authority / SRO / professional } \\
\text { body }\end{array}$ & USA (some States), Australia, Pakistan (proposed) \\
\hline 8. & $\begin{array}{l}\text { Infrastructure requirements } \\
\text { o Office premises } \\
\text { o Other accessories such as } \\
\text { hotlines / telephones, voice } \\
\text { recording system, facsmile } \\
\text { and e-mail accounts etc. }\end{array}$ & $\begin{array}{l}\text { Bahrain (suitable premises), Pakistan (proposed - premises and other } \\
\text { accessories), Malaysia (location) }\end{array}$ \\
\hline & Restrictions on activities & $\begin{array}{l}\text { Only money broking: Singapore, Hong Kong, Philippines, Bahrain and Taiwan } \\
\text { Confidentiality of information, Slovak Republic, Pakistan and India } \\
\text { Addditional activities are allowed. Conditions varied with activities : USA, UK, } \\
\text { Japan, Australia, Brazil, Malaysia and Malawi. }\end{array}$ \\
\hline 10. & $\begin{array}{l}\text { Condition to adhere any future guidelines, } \\
\text { rules or procedures to be adopted by the } \\
\text { authorizing authority }\end{array}$ & $\begin{array}{l}\text { Singapore, Hong Kong, Philippines, Malaysia, Taiwan, Malawi, Brazil, } \\
\text { Bahrain, USA (some states only), Australia, Japan and UK. }\end{array}$ \\
\hline 11. & $\begin{array}{l}\text { Required to maintain adequate accounting } \\
\text { and control systems and provide financial } \\
\text { statements and statistics to authorities }\end{array}$ & $\begin{array}{l}\text { Singapore, Hong Kong, Philippines Malaysia, Taiwan, Malawi, Brazil, Bahrain, } \\
\text { USA (some states only), Australia, Japan and UK. }\end{array}$ \\
\hline & $\begin{array}{l}\text { Holds the authority to revoke or void the } \\
\text { license }\end{array}$ & $\begin{array}{l}\text { Singapore, Hong Kong, Philippines, Malaysia, Taiwan, Malawi, Brazil, } \\
\text { Bahrain, USA, Australia, Japan and UK. }\end{array}$ \\
\hline & $\begin{array}{l}\text { Compulsory to become a member of a } \\
\text { SRO }\end{array}$ & USA and Pakistan (proposed) \\
\hline & $\begin{array}{l}\text { Time frame for commence business is } \\
\text { applied }\end{array}$ & USA (vary with activities involved and the State), Taiwan \\
\hline
\end{tabular}

In the majority of the countries in the sample, the credentials considered for registering as money broker are similar to those required in Sri Lanka. Some countries have enacted the procedures and they use somewhat similar practices followed by Sri Lanka. Most common feature in their licensing procedure is that the applicant should be a limited liability company registered under the respective laws. They issue the license after careful evaluation of the credentials of the company, promoter/brokers and other professionals and the viability of the company. The credentials commonly considered for granting license are given in Table 5 .

This study revealed that in many occasions, when MBs purely play a role of an agent by bringing two parties together to effect any transaction, authorities do not impose strict rules and regulations to control them. Wherever, strict regulations are in place, brokers are involved in extra activities which involve handling moneys of other parties. In some cases legislation are common for a wide range of activities some of which are carried out by MBs as well.

Furthermore, the Chart 3 indicates that no clear relationship exists between level of supervisory/regulatory activities and economic development. However, in developed markets, activities of the MBs are much more complex than in developing countries and therefore, in those countries supervisory and regulatory frameworks are strengthened.

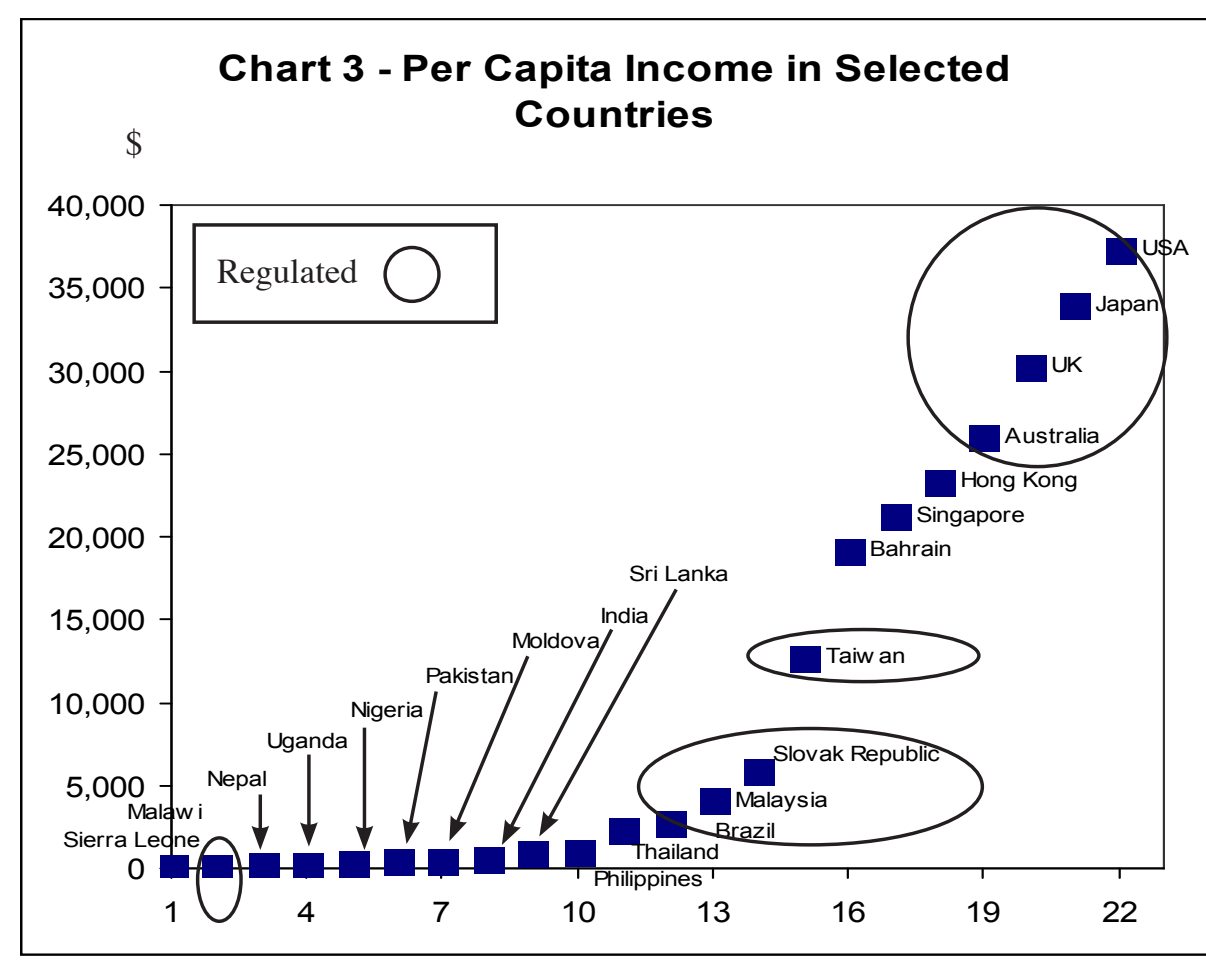

CENTRAL BANK OF SRI LANKA 
Table 6 - Summary of Licensing and Regulatory Practices of Money Brokers

\begin{tabular}{|c|c|c|c|}
\hline $\begin{array}{l}\text { Definition } \\
\text { and } \\
\text { Activities }\end{array}$ & Country & Licensing & Regulation and Supervision \\
\hline \multirow[t]{8}{*}{$\begin{array}{l}\text { As same as } \\
\text { Sri Lanka11 }\end{array}$} & India & Not required & $\begin{array}{l}\text { Do not come under any regulatory authority } \\
\text { as the MBs do not hold public funds. }\end{array}$ \\
\hline & Pakistan & $\begin{array}{l}\text { Not yet required, but in the } \\
\text { process of introducing licensing } \\
\text { requirement. To be registered } \\
\text { with Securities and Exchange } \\
\text { Commission of Pakistan (SECP) }\end{array}$ & $\begin{array}{l}\text { Not yet available, but in the process of } \\
\text { implementation. The Financial Market } \\
\text { Association is about to obtain mandate from } \\
\text { the Central Bank of Pakistan (CBP) and the } \\
\text { SECP as self regulatory organization. }\end{array}$ \\
\hline & Thailand & Not yet required. & $\begin{array}{l}\text { Regulatory framework is not yet available but } \\
\text { a study is being carried out about the scope } \\
\text { of permissible activities, the regulations and } \\
\text { supervision of MBs. }\end{array}$ \\
\hline & $\begin{array}{l}\text { Slovak } \\
\text { Republic }\end{array}$ & $\begin{array}{l}\text { Not required but money broking } \\
\text { companies are required to register } \\
\text { under the Company Law. }\end{array}$ & $\begin{array}{l}\text { No regulatory authority to supervise MBs. } \\
\text { They do have a self regulatory framework } \\
\text { developed within the industry. }\end{array}$ \\
\hline & Singapore & $\begin{array}{l}\text { It is required to obtain approval } \\
\text { from Monetary Authority of } \\
\text { Singapore (MAS) }\end{array}$ & $\begin{array}{l}\text { Apart from initial review at the point of } \\
\text { licensing, the MAS or any other regulatory } \\
\text { authority do not carry out supervision. }\end{array}$ \\
\hline & Hong Kong & $\begin{array}{l}\text { Licenses are issued by the Hong } \\
\text { Kong Monetary Authority (HKMA). }\end{array}$ & $\begin{array}{l}\text { No stringent regulatory framework to regulate } \\
\text { and supervise MBs. }\end{array}$ \\
\hline & $\begin{array}{l}\text { The } \\
\text { Philippines }\end{array}$ & $\begin{array}{l}\text { Licenses are issued by the } \\
\text { Securities and Exchange } \\
\text { Commission. }\end{array}$ & $\begin{array}{l}\text { The Securities and Exchange Commission. } \\
\text { is empowered to supervise and regulate the } \\
\text { MBs. If any doubt arises in relation to broker's } \\
\text { activities, the SEC consults the Bangko } \\
\text { Sentral ng Philippines (BSP). However, no } \\
\text { tight regulations imposed on MBs }\end{array}$ \\
\hline & Taiwan & \begin{tabular}{|l|} 
It is required to obtain a license \\
from Central Bank of China (CBC)
\end{tabular} & $\begin{array}{l}\text { Both Ministry of Finance and the CBC } \\
\text { are empowered to carry out supervision } \\
\text { of MBs. However, regulatory framework } \\
\text { is used to monitor the activities of the MBs } \\
\text { and to maintain the Business standards. } \\
\text { Both Ministry of Finance and CBC carry out } \\
\text { regulatory and supervisory functions. }\end{array}$ \\
\hline
\end{tabular}

11/ Please refer foot note 4

\begin{tabular}{|c|c|c|c|}
\hline $\begin{array}{l}\text { Definition } \\
\text { and } \\
\text { Activities }\end{array}$ & Country & Licensing & Regulation and Supervision \\
\hline \multirow{7}{*}{$\begin{array}{l}\text { As same as } \\
\text { Sri Lanka. } \\
\text { However, } \\
\text { same } \\
\text { legislation } \\
\text { covers } \\
\text { other } \\
\text { financial } \\
\text { businesses } \\
\text { which may } \\
\text { involve } \\
\text { systemic } \\
\text { risk }\end{array}$} & Malaysia & $\begin{array}{l}\text { It is required to obtain a license } \\
\text { from the Ministry of Finance (MOF). } \\
\text { The MOF will grant the license only } \\
\text { upon the recommendation of Bank } \\
\text { Negara Malaysia (BNM). }\end{array}$ & $\begin{array}{l}\text { The BNM is empowered to supervise anc } \\
\text { regulate licensed MBs. }\end{array}$ \\
\hline & Malawi & $\begin{array}{l}\text { The Reserve Bank of Malawi } \\
\text { (RBM) grant approval to MBs } \\
\text { with the approval of Ministry of } \\
\text { Finance. }\end{array}$ & $\begin{array}{l}\text { The RBM is empowered to supervise anc } \\
\text { regulate licensed MBs. }\end{array}$ \\
\hline & Brazil & $\begin{array}{l}\text { It is required to obtain a license } \\
\text { from the Central Bank or Securities } \\
\text { Exchange Commission. }\end{array}$ & $\begin{array}{l}\text { All licensed brokers are subject to the regula } \\
\text { supervision of the Central Bank or Securities } \\
\text { Exchange Commission depending on the } \\
\text { activities carried out by them. }\end{array}$ \\
\hline & Bahrain & $\begin{array}{l}\text { It is required to obtain a license } \\
\text { from Bahrain Monitory Authority } \\
\text { (BMA) }\end{array}$ & $\begin{array}{l}\text { As the existing law does not define 'banking } \\
\text { services' all the activities relating to financia } \\
\text { services are regulated by the BMA. However } \\
\text { proposed law identifies money broking as } \\
\text { 'non-regulated service'. }\end{array}$ \\
\hline & USA & $\begin{array}{l}\text { Common rules and regulations } \\
\text { are applied to both dealers and } \\
\text { brokers. Both general purpose } \\
\text { dealers and brokers are required } \\
\text { to register with } \\
\text { o the Security Exchange } \\
\text { Commission (SEC) } \\
\text { o Self Regulatory Organization } \\
\text { approved by the government } \\
\text { o Comply with the State legal } \\
\text { requirements simultaneously. } \\
\text { Dealer/broker who limits his } \\
\text { activities to government securities } \\
\text { market is required to follow the } \\
\text { rules and regulations imposed by } \\
\text { both US Treasury and SEC. }\end{array}$ & $\begin{array}{l}\text { Self Regulatory Organisations (SROs) assis } \\
\text { the SEC in regulating the activities of brokers } \\
\text { i.e., National Association of Security Dealers } \\
\text { and the National Securities Exchange. } \\
\text { Requirements differ from State to State. }\end{array}$ \\
\hline & $\begin{array}{l}\text { North Dakota } \\
\text { (A State of } \\
\text { USA) }\end{array}$ & $\begin{array}{l}\text { The Department of Financial } \\
\text { Institutions regulates the money } \\
\text { broker licensing in North Dakota. } \\
\text { Even for operating as a Mortgage } \\
\text { Broker in the state of North Dakota, } \\
\text { an applicant is required to obtain } \\
\text { the money broker license in the } \\
\text { State. }\end{array}$ & $\begin{array}{l}\text { The Consumer Division of the Department } \\
\text { of Financial Institutions regulates MBs. }\end{array}$ \\
\hline & Australia & $\begin{array}{l}\text { All brokers need to obtain licenses } \\
\text { from the Australian Securities and } \\
\text { Investment Commission (ASIC). } \\
\text { In addition, stock brokers are } \\
\text { required to register with Australian } \\
\text { Stock Exchange (ASX). Financial } \\
\text { brokers hold a current business } \\
\text { certificate and alicense obtain from } \\
\text { Finance Broker Supervisory Board } \\
\text { established under the Section } 26 \\
\text { of the Finance Brokers Control Act } \\
\text { of } 1975 \text { (amended in 2003). }\end{array}$ & $\begin{array}{l}\text { The ASIC supervise all brokers while } \\
\text { overseeing activities of ASX. } \\
\text { The Finance Broker Supervisory Board is } \\
\text { responsible for supervision and regulation } \\
\text { of finance brokers (Part IV of the Finance } \\
\text { Broker Control Act). }\end{array}$ \\
\hline
\end{tabular}




\begin{tabular}{|c|c|c|c|}
\hline $\begin{array}{l}\text { Definition } \\
\text { and }\end{array}$ & Country & Licensing & Regulation and Supervision \\
\hline & UK & $\begin{array}{l}\text { The Financial Services authority } \\
\text { (FSA) is responsible for the } \\
\text { authorization and supervision of } \\
\text { financial institutions, and for the } \\
\text { supervision of financial markets } \\
\text { and clearing and settlement } \\
\text { systems. It is also responsible for } \\
\text { regulatory policy in these areas. }\end{array}$ & $\begin{array}{l}\text { The FSA plays a role of supervisor of all } \\
\text { financial institutions in UK. Self regulating } \\
\text { institutions such as British Insurance Brokers } \\
\text { Association are committed to playing a } \\
\text { central role in the industry. }\end{array}$ \\
\hline $\begin{array}{l}\text { Two types } \\
\text { of MBs } \\
\text { i.e. money } \\
\text { market } \\
\text { broker-cum- } \\
\text { dealers } \\
\text { and foreign } \\
\text { exchange } \\
\text { brokers }\end{array}$ & Japan & $\begin{array}{l}\text { Broker cum dealers are required } \\
\text { to register with the Bank of Japan } \\
\text { (BOJ) and the Financial Services } \\
\text { Agency (FSA). } \\
\text { Brokers should register only with } \\
\text { the FSA. }\end{array}$ & $\begin{array}{l}\text { The BOJ carry out supervision of Broker/ } \\
\text { Dealer firms but it has no administrative } \\
\text { powers. } \\
\text { The FSA supervise and regulate both type } \\
\text { of MBs. } \\
\text { The FSA is given the mandate to conduct } \\
\text { on-site inspections and to ask financial } \\
\text { institutions to submit reports or material on } \\
\text { their business of finance. }\end{array}$ \\
\hline $\begin{array}{l}\text { There } \\
\text { are no } \\
\text { institutions } \\
\text { explicitly } \\
\text { agreeing } \\
\text { with } \\
\text { definition } \\
\text { as Money } \\
\text { broking } \\
\text { is not yet } \\
\text { developed } \\
\text { to a } \\
\text { significant } \\
\text { level. }\end{array}$ & $\begin{array}{l}\text { Nigeria } \\
\text { Uganda, } \\
\text { Sierra Leone, } \\
\text { Nepal and } \\
\text { Moldova }\end{array}$ & \multicolumn{2}{|c|}{ Legal framework is not yet implemented } \\
\hline
\end{tabular}

\section{Concerns for Sri Lanka's Money Broking Industry}

This study clearly indicates following observations.

- Money broking activities are not significant: Countries where the money broking activities are not carried out explicitly or not significant in volume, legislative framework to regulate or supervise the MBs is not yet available. Under the current conditions it difficult to comment whether licensing or regulatory framework would be implemented eventually. Twenty four per cent of the countries in the sample (Nigeria Uganda, Sierra Leone, Nepal and Moldova) do not impose any regulations on MBs due to this reason.
- Believe no systemic risk and no regulatory framework or promote self regulation: Another 10 per cent of the countries in the sample (India and Slovak Republic) which have developed money broking industry have not used any licensing or regulatory framework to regulate MBs as this industry has no risk to the financial system or the savings of the public. Another 10 per cent of the countries in the sample (Pakistan and Thailand) with developing money broking industry who do not use any regulations on MBs so far, have taken steps to develop regulatory framework. These countries have felt that some form of licensing may be required with the expansion of the industry to avoid any malpractices and to monitor the development. However, they promote self regulation.

- Believe no systemic risk, regulatory framework is in place but lenient approach in regulating: Another 24 per cent of the countries in the sample (Singapore, the Philippines, Hong Kong, Taiwan and Bahrain) which have licensing procedures in place do not pay keen interest to regulate or supervise MBs. These countries, though the regulations are in place, do not impose them seriously as they feel it is not essential as the industry has not caused any systemic risk. Countries like Hong Kong and Taiwan use a very lenient approach in regulating but expect some form of coordination to monitor their activities. In the case of Bahrain, new legislation has clearly defined money broking activities as unregulated activity.

- Tight regulation as MBs carry out additional businesses or the legislation cover additional businesses: The balance 33 per cent of the countries (USA, UK, Australia, Japan, Malaysia, Malawi and Brazil) which have well established licensing and regulating framework, money broking activities cannot be identified separately as in these countries $(a)$ brokers are defined together with dealers, $(b)$ money brokers are defined together with mortgage brokers, insurance brokers, capital market brokers etc., (c) money brokers carry out a series of activities and some involve high risk factor i.e., in Japan companies involving a in money broking and dealers activities have access to BOJ's funding facilities, in the US, some MBs do primary dealer businesses, in Australia, internet brokers are involved in all kinds of broking activities including stock broking/dealing activities $(d)$ money broking activities are carried out as a secondary source of activity together with underwriting, deposit accepting, lending etc. (i.e., Brazil).

This evidence clearly indicate that wherever, money broking activities can be clearly identified, the authorities do not pay much attention to regulate or supervise them but prefer to have some form of licensing or granting approval to commence businesses. Many countries (57 per cent) issue license or other form of approval to commence business as a money broker. The other two countries may introduce licensing procedures in the near future. 


\section{A. Reasons for having interest on licensing}

(a) Financial sector stability is the common interest of many Central Banks/monetary authorities in the world and therefore, it is essential for them to monitor the activities of all important financial institutions as much as possible. Such monitoring enables the monetary authorities to measure the developments in the financial sector, identify risk elements involved and to impose any regulations whenever required. Issue of license or granting permission in other form provide an opportunity for monetary authorities to access money broking companies if required. Therefore, some countries include conditions when the license is granted and some keep provisions to impose any conditions whenever the authority feels, the necessity.

(b) To give credence to the operations of MBs and provide confidence for financial institutions to use their broking services.

(c) To prevent the entrance of non-qualified persons to the business and to maintain the common practice and fair playing field to all firms in the business. To maintain the high standards of the business. Many countries examine the quality of the money brokers employed by the company through evaluation of their professional qualifications, past experience, track records i.e., whether they have been blacklisted etc., to make sure whether the person is competent enough to accept as a specialist in the field of broking.

(d) To ensure the legality of the firm. Many countries require the firm to be registered as a limited liability company. Other countries too consider whether required legal conditions are fulfilled.

(e) To maintain the record of existing market players as money brokers have an important role to play in the money market.

(f) To monitor the development in the business in the context of national economy through the collection of information.

The survey results provide evidence that the countries where $(a)$ money broking activities are not developed to a significant level or $(b)$ MBs carry out the business within the definition of merely 'money broker' i.e., only acting as an agent, using his expertise to bring two parties together, borrower and lender for a fee and do not hold any of those funds in their portfolios even for a very short period, the monetary authority or any other authority do not take any interest to supervise or regulate such business.

\section{B. Reasons for not having interest on Regulating $M B$ s}

On the above grounds, as the MBs in Sri Lanka too fall into the same definition, necessity does not arise for the CBSL or any other authority to regulate or supervise the MBs in Sri
Lanka. However, it is appropriate for the CBSL to monitor the nature and volume of their activities as a measure of the development in the financial sector.

Major arguments in favour to this conclusion are

- According to the widely accepted definition, money brokers, are agents who bring two parties together enabling them to enter into contract to which they are not principals. They do not accept deposits or lend money but provide a service using their expertise in the business. They are paid for the service, a fee which is calculated based on the value of the transaction. Hence, MBs do not handle public funds.

- Monetary authorities are concerned about the soundness of a financial institution, based on its systemic importance and the exposure to the overall economy. Failure of such an institution may cause a risk to the stability of the overall financial system. In Sri Lanka, Financial Stability Review Report identifies licensed commercial banks, Employees Provident Fund, primary dealers, licensed specialized banks, and non-bank financial institutions as systemically important financial institutions (SIFI) that could pose a risk to the stability of the overall financial system. These institutions hold more than 75 per cent of the total financial sector assets and are supervised and regulated by the CBSL. There are a number of other institutions some of which are deposit taking institutions (co-operative rural banks, co-operative banks etc.), contractual savings institutions (Employees Trust Fund, insurance institutions etc.), and other specialized financial institutions (merchant banks, venture Capital, unit trust) which hold public funds but are not supervised or regulated by the CBSL. As such, there is no justification for the CBSL to regulate or supervise the MBs which do not even deal with public funds and also since the MBs have a negligible impact on the financial system.

- The financial institutions, experience various types of risks while carrying out their business. The monetary authorities or regulators determine the soundness of the firm through its efficiency and effectiveness of risk management.

- Credit Risk is the risk arising from borrowers failing to repay their dues on time These type of risk is involved with lending institutions. MBs do not lend money or do not provide services on credit. They do not find debtors in the course of day to day activities. Therefore, MBs are not-vulnerable for credit risk.

- Liquidity Risk: The financial institutions face liquidity risk when they fail to meet its financial obligations. As MBs do not accept deposits and operate on their own funds liquidity risk does not arise.

- Market Risk: Generally, financial institutions face market risk due to adverse movements in interest rates and exchange rates, changing tax policies, changing prices of investments and trading activities in the securities market. However, activities of MBs do not link with any of those factors and their charges or fee 
is based on the volume of successful transactions they negotiated on behalf of the customers. Generally, fee per unit is also pre-determined. In most countries, including Sri Lanka, all MBs charge standard fee for similar transactions.

- Operational Risk: There is a possibility for the MBs to face operational risk due to lack of experienced staff, system failures, wrong management techniques and procedures etc. This may cause losses to their customers (i.e., If MBs fails to find the best possible offer to its customer due to lack of specialty). However, such losses may not cause any serious harm to the customer firms but such MBs will be out of business soon as fair amount of competition exists. The licensing authority always consider this factor when granting permission to start business as a money broker.

- Systemic Risk: As identified in the Financial Stability Review Report-2005, MBs do not belong to the systemically important financial institutions that could create a risk to overall financial system stability.

- The Majority of MBs, operate with a small capital. In Sri Lanka this range from Rs.450,000/- to Rs.14 million except for one company which has a capital of Rs.10,000/-. Taiwan, Singapore, Hong Kong, Brazil and Pakistan (proposed) have imposed relatively small capital requirement limits ${ }^{12}$. As most of these companies are limited liability companies their liability is limited to the capital.

All these factors conclude that risk involved in MBs to the public or to the overall financial system is negligible.

\section{Recommendations}

1. Currently all ten MBs operating in Sri Lanka are largely involved in the inter bank call money market, foreign exchange market and government securities market which have more market opportunities and scope for future expansion. However, a large share of these markets is yet to be harnessed by the money brokers. As the opportunities for MBs are increasing there is no constrain on profitability and therefore, a capable and professional money broker could be able to perform profitably under the current market conditions.

2. Even though, there is no legal framework to approve, regulate or supervise the money broking firms in Sri Lanka, the CBSL has a well established procedure to evaluate and grant permission to carry out money broking activities in Sri Lanka through the practice of issuing a 'no objection' letter. The CBSL has issued the 'no objection' letters after

\footnotetext{
12/ Please refer Table 5.
}

the assurance of legality of the proposed company and reviewing market conditions, competence of the staff of the individual firms and the feasibility of the firms.

The procedure that Sri Lanka is adopting to grant permission to a money broker who carries out only money broking business as defined in this study ${ }^{13}$ seems to be practiced by many other countries even with developed financial systems than in Sri Lanka. In some countries the procedure is well documented and enacted as legislation (Table 5). Therefore, the need does not arise for the CBSL to amend the existing procedure of granting permission for carrying out money broking business in Sri Lanka.

3. As long as MBs operate within the given definition, operations of the MBs will not cause any systemic risk to the financial stability of the country. If a money broker company is involved in acceptance of deposits of public funds, or is involved in stock broking as a part of their business, under the current law, it comes under the preview of the CBSL and SEC, respectively. Therefore, as far as MBs are within the current definition, it is not necessary for CBSL, Ministry of Finance or any other government body to be involved in supervision or regulating money broking business in Sri Lanka.

4. In none of the countries in the sample, licensing/regulating authorities consult nor obtain permission from respective professional organizations (i.e., money broker associations) when licenses are issued to new comers. In Sri Lanka too, other professional bodies such as the Primary Dealers' Association, the Forex Association and the Bankers' Association are not consulted when the regulating authority grants license to new entrants to their professional fields. Therefore, need does not arise for the CBSL to consult the SLMBA when the CBSL grant permission to new entrants.

5. The study reveals that licensing power is always with the government authorities and in some cases supervisory role is carried out by the SRO. None of those countries recognizes SROs as a supervisory body unless they are governmental own or have developed their reputation over the years through the standards maintained in their practice. In the USA, all prospective applicants to become brokers should apply for a membership in a reputed SROs or a registered National Securities Exchange simultaneously while applying for the broking license. These SROs have developed their reputation and received government recognition through providing effective and quality services. For example, the National Association of Security Dealers (NASD), one of the world's leading SROs in the USA, achieved its reputation by helping to bring integrity to the markets and confidence to investors through more than 60 years in service. In addition to the role of primary private sector regulator of US broking industry, it provides a variety of services to the development of the industry such as outsourced regulatory products and services to a number of stock markets and exchanges, provide

13/ All MBs in Sri Lanka come under this definition. 
education and conduct examinations to give professional qualifications to industry professionals and operate the largest securities Dispute Resolution Forum. Similarly, the Financial Market Association of Pakistan has been recognized by the CBP as a SRO, after seven years active service to promote the educational, professional, ethical and social interests of the financial markets and banking industry and developed International Standardized Best Practices and Code of Conduct to the industry. Even in Sri Lanka the Colombo Stock Exchange (CSE) is a self-regulatory organization licensed by the Securities and Exchange Commission of Sri Lanka (SEC) to operate the stock market in Sri Lanka. The CSE has a set of regulations which both provide trading and clearing infrastructure for securities trading in Sri Lanka and also enables the CSE to act as a Self Regulatory Organization (SRO). Hence, SLMBA too should endeavour to develop its reputation by introducing quality services and practice to its members and to the market rather than requesting official recognition from the Authorities.

6. It is appropriate for the CBSL to encourage the SLMBA to have close dialogue with the CBSL. However, the building up of its own reputation should come through the quality of its services rendered to own members, their customers and the development of the industry. Currently, all MBs operating in Sri Lanka are members of the SLMBA. The SLMBA should develop its image and the reputation to an acceptable level to be attractive to any new entrants to obtain the membership of the Association.

7. The CBSL should also build up a data base to monitor the trade performance of MBs on regular basis to evaluate their contribution to the overall financial sector and the their role in the economy. This will help the CBSL when it evaluate the feasibility of new entrants to the industry.

8. The SLMBA should develop its own Code of Ethics and Professional Conduct acceptable to all parties, involved in the business and follow that to build up its credibility in the market as the SRO. The Code of Conduct and Constitution proposed by the SLMBA is still at the draft stage. Therefore, the SLMBA should give priority to develop this draft to an acceptable level and use it to lay a solid foundation to boost up its reputation as the SRO for MBs.

\section{Questionnaire on Money Brokers}

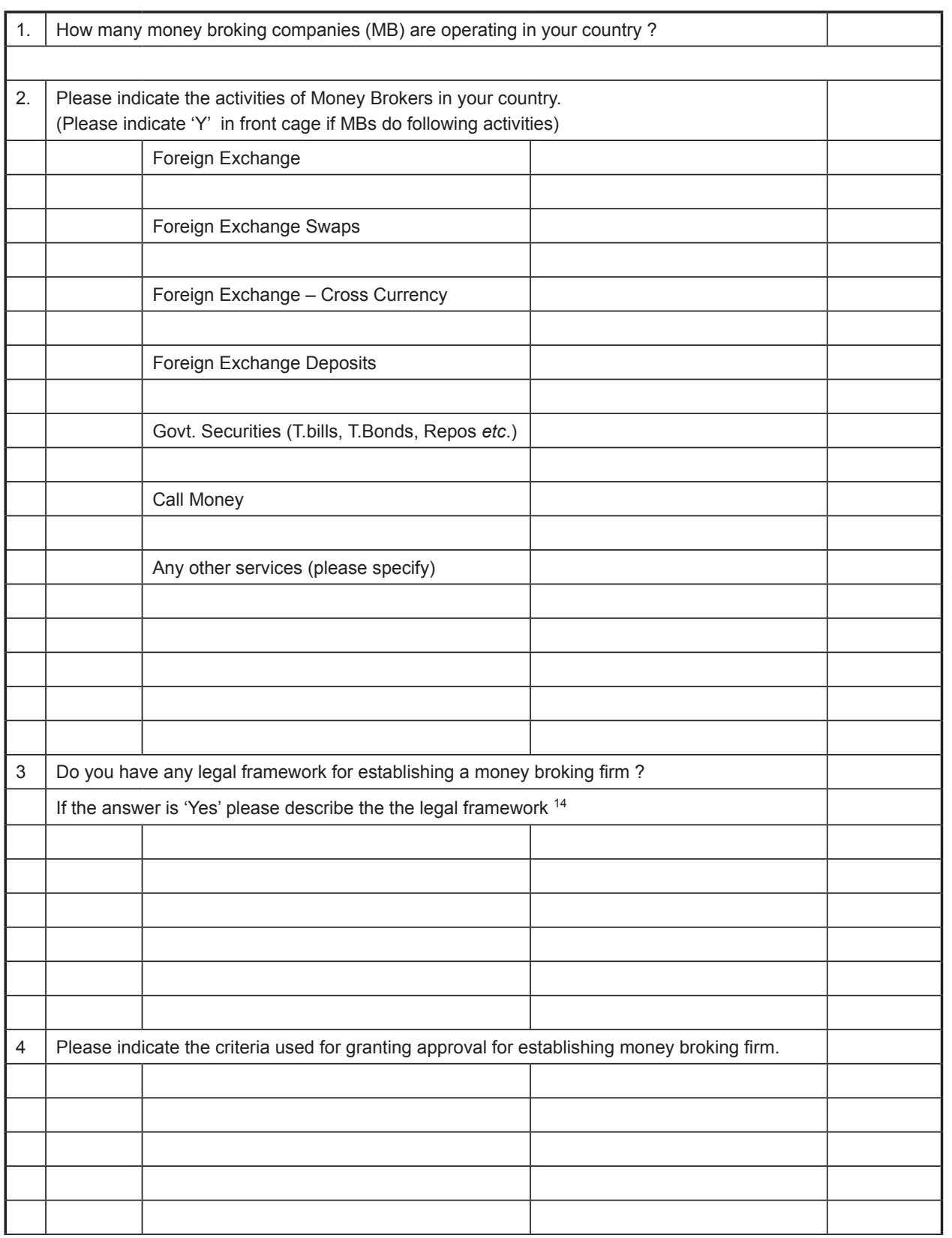

14/ A copy of the relevant legislation with regulations and guidelines issued if any will be appreciated. 


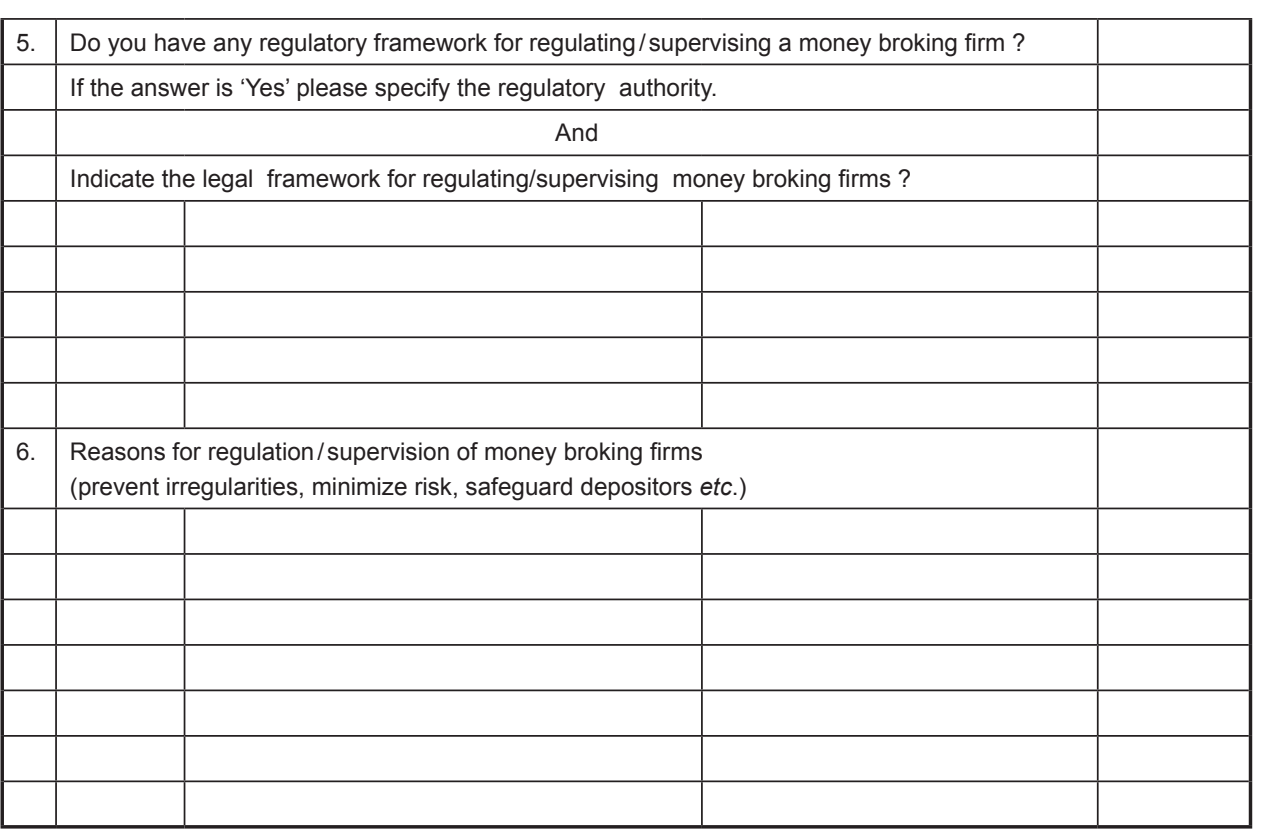

Thank You

15/ Copies of any guidelines issued and/or operational manual will be useful.

\section{REFERENCE}

Bahrain Monitory Agency, 2004, Bahrain Country Commercial Guide FY 2004.

Bahrain Monitory Agency, 2004, Developing an Integrated License Framework, BMA Consultation Paper, December, 2004.

Bahrain Monitory Agency, 2004, Standard Conditions and Licensing Criteria for a Broking Company License.

Baker \& Mckenzie, 2000, Internet Banking - Key Legal Considerations Regional Overview - Japan -www/baknet.com/ecommerce/banking-financial.

Bank of Japan, 2000, Functions and Operations of Bank of Japan, December 2000.

Bank of Thailand , 2003, Report on Private Repurchase Market, Market Research and Development Team, Financial Markets and Reserve Management

Beate Reszat, 2003, Japan's Financial Markets: The Lost Decade, HWWA Discussion Paper 231, Hamburg, Institute of International Economics

Central Bank of China, 2004, Laws and Regulations, Regulations Governing Establishment and Operations of Foreign Bankers.

Central Bank of Sri Lanka, 2004, Financial Stability Review - 2004.

Department of Financial Institutions, North Dakota, www.mortgageleadguide.com

Financial Brokers Supervisory Board, Australia , 2005, www.financebrokers.wa.gov.au

Financial Services Agency, 2001, The Role of financial services Agency.

Frank J Abuzz and Michael D Joehnk, Introduction of Fixed Income Securities, Unpublished.

Jon Denovan, 2004, Overseas Broker Regulation, Gadens Lawyers, December 2004.

Licensing Status Report, 2001, www.mlnusa.com/liceses.htm. Laws of Malaysia Act 372, Banking and Financial Institution Act 1989.

Masaharu Hino, 2000, On the Establishment of the Financial Services Agency, Presentation at the Bank of England, September 2000.

Mallam Nuhu Ribabu, 2003, Perspectives of the new Regulatory and Legal Landscape for Financial Intermediaries in Nigeria - Potential for Improvement, Presentation at the 21 st Cambridge Symposium on Economic Crimes, London, September, 2003.

\section{Money Brokers}

Bartleet Mecklai and Roy Ltd.

Capital Alliance Money Brokers Ltd.

CSF Money Broking Company

First Capital Money Brokers Ltd.

Mercantile Finance Brokers Ltd.

Pigott Chapman \& Company

SMB Money Brokers (Pvt.) Ltd. 
Taprobane Investments (Pvt.) Ltd.

Vanik Money Brokers Ltd.

National Association of Financial Market Institutions, 2003, Brazilian Financial System Institutional Framework, 2003.

Regulations for Licensing of Dealers and Brokers, 2004, www.rbm.malawi.net/FMO/d\&b.htm

Sheaeman \& Sterling Llp. 2004, Selected Issues Regulating the Formation and Registration of United States Broker-Dealer, August 2004.

The Banking (Amendment) Ordinance, Hong Kong, 1997, Chapter 11.

U.S. Securities and Exchange Commission, 2004, Guide to Broker-Dealer Registration, August 2004.

World Bank, 2005, World Development Report. 